\title{
Peran Pemerintah Dalam Penyelenggaraan Kesehatan Dan Jaminan Sosial Negara Demokrasi
}

\author{
Alfara Derista Felany \\ Institut IImu Kesehatan Strada Indonesia \\ alfaraderista05@gmail.com
}

\begin{abstract}
Abstrak
Demokrasi sebagai sistem pemerintahan yang mengijinkan dan memberikan hak, kebebasan kepada warga negaranya untuk berpendapat serta turut serta dalam pengambilan keputusan di pemerintahan. Kesehatan merupakan pelayanan publik yang bersifat mutlak dan erat kaitannya dengan kesejahteraan masyarakat. Untuk semua pelayanan yang bersifat mutlak, negara dan aparaturnya berkewajiban untuk menyediakan layanan yang bermutu dan mudah didapatkan setiap saat. Pelayanan di bidang kesehatan merupakan salah satu bentuk pelayanan yang paling banyak dibutuhkan oleh masyarakat. Pelayanan kesehatan merupakan langkah peningkatan kesejahteraan masyarakat dan hal ini sangat penting dalam rangka meningkatkan kualitas Sumber Daya Manusia (SDM). Salah satu usaha peningkatan kesehatan pada masyarakat tersebut dapat dilakukan dengan cara menyediakan fasilitas pelayanan kesehatan yang merata. Akses kepada pelayanan kesehatan menjadi lebih mudah dengan tidak membebani kemampuan finansial masyarakat.
\end{abstract}

\section{Latar Belakang}

Sebagai negara yang mempunyai jumlah penduduk yang besar, kesehatan adalah salah satu unsur utama dalam setiap kehidupan seseorang, karena kesehatan seseorang sangat menunjang aktivitas kesehariannya (Isriawaty 2015). Salah satu usaha peningkatan kesehatan pada masyarakat dapat dilakukan dengan cara menyediakan fasilitas pelayanan kesehatan yang merata dan sesuai dengan keinginan masyarakat yang dilayani. Fasilitas pelayanan kesehatan merupakan suatu alat dan/atau tempat yang digunakan untuk menyelenggarakan upaya pelayanan kesehatan, baik promotif, preventif, kuratif maupun rehabilitatif yang dilakukan oleh pemerintah, pemerintah daerah, dan/atau masyarakat (Notoatmodjo 2010). Saat ini derajat kesehatan masyarakat masih rendah khususnya masyarakat miskin, hal ini dapat dilihat dari masih tingginya angka kematian ibu dan angka kematian bayi. Salah satu penyebab hal tersebut 
karena mahalnya biaya kesehatan sehingga akses ke pelayanan kesehatan pada umumnya masih rendah. Banyak faktor yang menyebabkan ketimpangan di dalam pelayanan kesehatan terutama yang terkait dengan biaya pelayanan kesehatan (Hadi Mahmud 2014). Akses kepada pelayanan kesehatan menjadi lebih mudah dengan tidak membebani kemampuan finansial masyarakat sebagaimana yang diharapkan dalam Universal Health Coverage (UHC) atau cakupan kesehatan semesta.

\section{Kasus/masalah}

1) Bagaimana kewajiban pemerintah dalam penyelenggaraan kesehatan?

2) Bagaimana upaya pemerintah dengan tidak membebani kemampuan finansial masyarakat?

\section{Tinjauan Pustaka}

Sebuah negara hukum, sesungguhnya yang memerintah adalah hukum, bukan manusia. Hukum dimaknai sebagai kesatuan hirarkis tatanan norma hukum yang berpuncak pada konstitusi. Hal ini berarti bahwa dalam sebuah negara hukum menghendaki adanya supremasi konstitusi. Supremasi konstitusi disamping merupakan konsekuensi dari konsep negara hukum, sekaligus merupakan pelaksanaan demokrasi karena konstitusi adalah wujud perjanjian sosial tertinggi (Asshiddiqie 2005). Negara hukum dalam perkembangannya senantiasa dipautkan dengan konstitusi negara, terutama dalam hal pengaturan dan penegasan tentang pembatasan kekuasaan negara untuk menjamin kemerdekaan dan hak-hak dasar warga negara dan perlindungannya. Esensi dari negara berkonstitusi adalah perlindungan terhadap hak-hak asasi manusia. Atas dasar itu, keberadaan konstitusi dalam suatu negara merupakan kemutlakan. Menurut Sri Soemantri (Hakim 2006), tidak ada satu negarapun di dunia ini yang tidak mempunyai Konstitusi atau undang-undang dasar, Negara dan konstitusi merupakan dua lembaga yang tidak dapat dipisahkan satu dengan yang lain. Dengan demikian dalam batas-

batas minimal, negara hukum identik dengan negara yang berkonstitusional atau negara yang menjadikan konstitusi sebagai aturan main kehidupan kenegaraan, pemerintahan, dan kemasyarakatan (Asshiddiqie 2003). Indonesia adalah negara yang berdasarkan atas hukum menurut Pasal 1 ayat (3) Undang-Undang Dasar Negara Republik Indonesia Tahun 1945. Pasal ini menghendaki bahwa penyelenggaraan pemerintahan didasarkan atas prinsip-prinsip hukum untuk membatasi kekuasaan pemerintah dan ini artinya kekuasaan negara melalui aparatnya dibatasi oleh hukum (rechtsstaat), bukan didasarkan atas kekuasaan (machtsstaat). Hukum 
yang baik adalah hukum yang demokratis, yang didasarkan atas kehendak rakyat sesuai dengan kesadaran hukum rakyat, sedangkan hukum yang adil adalah hukum yang sesuai dan memenuhi maksud dan tujuan setiap hukum, termasuk dalam bidang kesehatan (Dayanto 2013).

Peraturan Presiden No. 82 Tahun 2018 tentang Jaminan Kesehatan yang mengatur dukungan Pemerintah Daerah dalam penyelenggaraan Jaminan Kesehatan. Beberapa bentuk dukungan yang diatur dalam Perpres tersebut di atas seperti: peningkatan pencapaian peserta di wilayahnya, kepatuhan pembayaran iuran, peningkatan pelayanan kesehatan dan bentuk dukungan lainnya merupakan hal yang wajib dilakukan oleh Pemerintah Daerah dalam rangka menjaga kesinambungan Jaminan Kesehatan Nasional (JKN).

\section{Pembahasan}

1) Kewajiban pemerintah dalam upaya penyelenggaraan kesehatan

Kehadiran Negara bertujuan untuk memenuhi kebutuhan hidup setiap warga negara. Negara berkewajiban melaksanakan fungsinya menyediakan kebutuhan hidup yang berkaitan dengan hidup masyarakatnya. Salah satu contoh kebutuhan publik yang mendasar adalah kesehatan. Hak atas kesehatan merupakan salah satu hak asasi manusia dan salah satu unsur kesejahteraan yang harus diwujudkan untuk mencapai cita-cita bangsa Indonesia. Tingkat kesehatan merupakan salah satu indikator pengukuran tingkat kesejahteraan dan kemakmuran suatu negara. Negara yang tingkat kesejahteraannya tinggi akan memiliki tingkat kesehatan masyarakat yang baik pula, begitu pula sebaliknya. Kesehatan sebagai salah satu unsur kesejahteraan umum harus diwujudkan sesuai dengan cita-cita bangsa. Dengan demikian pemerintah mempunyai tanggung jawab mengenai masalah kesehatan masyarakat. Salah satu cara yang ditempuh oleh pemerintah untuk mengatasi masalah kesehatan yang ada di masyarakat yakni dengan mengeluarkan kebijakan mengenai pelayanan kesehatan bagi masyarakat. Undang-undang Nomor 36 Tahun 2009 metegaskan bahwa setiap orang mempunyai hak yang sama dalam memperoleh akses atas sumber daya di bidang kesehatan dan memperoleh pelayanan kesehatan yang aman, bermutu, dan terjangkau. Setiap peserta berhak memperoleh manfaat jaminan kesehatan yang bersifat pelayanan kesehatan perorangan, mencakup pelayanan promotif, preventif, kuratif dan rehabilitative.

Tanggung jawab pemerintah dimkasud adalah dalam hal sebagai berikut: Merencanakan, mengatur, menyelenggarakan, membina, dan mengawasi penyelenggaraan upaya kesehatan yang merata dan terjangkau oleh masyarakat. Ketersediaan lingkungan, tatanan, fasilitas kesehatan baik fisik maupun sosial bagi 
asyarakat untuk mencapai derajat kesehatan yang setinggi-tingginya. Ketersediaan sumber daya di bidang kesehatan yang adil dan merata bagi seluruh masyarakat untuk memperoleh derajat kesehatan yang setinggi-tingginya. Ketersediaan akses terhadap informasi, edukasi, dan fasilitas pelayanan kesehatan untuk meningkatkandan memelihara derajat kesehatan yang setinggi-tingginya. Memberdayakan dan mendorong peran aktif masyarakat dalam segala bentuk upaya kesehatan. Ketersediaan segala bentuk upaya kesehatan yang bermutu, aman, efisien, dan terjangkau. Pelaksanaan jaminan kesehatan masyarakat melalui sistem jaminan sosial nasional bagi upaya kesehatan perorangan sesuai dengan ketentuan peraturan perundang-undangan. Dalam rangka melaksanakan tanggung jawab tersebut, pemerintah melakukannya berdasarkan asas perikemanusian, keseimbangan, manfaat, pelindungan, penghormatan terhadap hak dan kewajiban, keadilan, gender dan nondiskriminatif dan norma-norma agama.

2) Upaya pemerintah tidak membebani kemampuan finansial masyarakat

Penyelanggaraan jaminan sosial merupakan kewajiban negara yang diamanatkan oleh Undang-Undang Dasar Negara Republik Indonesia Tahun 1945. Sistem Jaminan Sosial Nasional merupakan salah satu perwujudan tanggung jawab negara dalam rangka menjamin kesejahteraan rakyatnya.

Penyelenggaraan Jaminan Kesehatan Nasional (JKN) yang dimulai sejak tahun 2014 telah memberikan banyak manfaat bagi masyarakat Indonesia. Akses kepada pelayanan kesehatan menjadi lebih mudah dengan tidak membebani kemampuan finansial masyarakat sebagaimana yang diharapkan dalam Universal Health Coverage (UHC) atau cakupan kesehatan semesta. Penyelenggaraan UHC di Indonesia dilakukan dengan pembagian kewenangan antara Pemerintah Pusat, Pemerintahan Daerah dan BPJS Kesehatan. Dalam hal ini, penyelenggaraan JKN sebagai pembiayaan kesehatan dilakukan terpusat oleh BPJS Kesehatan, sementara Daerah berperan dalam menyelenggarakan layanan kesehatan bagi peserta JKN. Dari pembagian kewenangan ini, maka hubungan keuangan antara Pemerintah Pusat dan Pemerintahan Daerah hanya terbatas pada kewenangan yang dirinci dalam UU Pemerintah Daerah dan tidak turut serta dalam penyelenggaraan pembiayaan kesehatan oleh JKN. Peran Pemerintahan Daerah dalam JKN terbatas dalam hal untuk memastikan kepesertaan penduduk di wilayahnya dengan memberikan bantuan iuran yang berasal dari APBD. Dalam kaitannya dengan risiko finansial JKN, Pemerintahan Daerah berkontribusi dalam bentuk pemotongan penerimaan pajak rokok yang menjadi hak daerah untuk disetorkan langsung kepada BPJS Kesehatan melalui mekanisme sebagaimana yang diatur oleh Menteri Keuangan. 


\section{Kesimpulan}

Demokrasi dengan berbagai eksesnya, di satu sisi membawa dampak yang baik. Kesempatan untuk masyarakat agar lebih berkembang dalam bidang sosial, ekonomi dan politik terbentang lebih luas. Pelayanan kesehatan adalah sebuah konsep yang digunakan dalam memberikan layanan kesehatan kepada masyarakat. Pelayanan kesehatan merupakan sebuah sub sistem pelayanan kesehatan yang tujuan utamanya adalah pelayanan preventif (pencegahan) dan promotif (peningkatan kesehatan) dengan sasaran masyarakat. Pelayanan kesehatan diselenggarakan sendiri/secara bersamasama dalam suatu organisasi untuk memelihara dan meningkatkan kesehatan, mencegah, dan menyembuhkan penyakit serta memulihkan kesehatan peroorangan, keluarga, kelompok, atau masyarakat. Jaminan pelayanan kesehatan merupakan salah satu bentuk perlindungan yang diselenggarakan negara guna menjamin warga negara untuk memenuhi kebutuhan dasar hidup yang layak. Menyatukan seluruh pembiayaan kesehatan pada dana jaminan sosial kesehatan untuk membiayai kegiatan pelayanan kesehatan baik individu dan masyarakat yang dijalankan dengan kebijakan yang merespon kebutuhan lokal diharapkan menjadikan penyelenggaraan UHC di Indonesia lebih optimal.

\section{Daftar Pustaka}

Buku :

Siyoto, S., \& Sodik, M. A. (2015). Dasar metodologi penelitian. Literasi Media Publishing.

Artikel Jurnal :

Timon, A. (2020). Tanggung Jawab Negara Hukum Demokrasi dalam Penyelenggaraan Pelayanan Kesehatan. Soumatera Law Review, 3(1), 18-29.

Martira, A., \& Nursadi, H. (2020). HUBUNGAN KEUANGAN PEMERINTAH PUSAT DAN DAERAH DALAM PENYELENGGARAAN JAMINAN KESEHATAN NASIONAL. Jurnal Hukum \& Pembangunan, 50(1), 177-199. 